\title{
Liver transplant outcome: a comparison between high and low MELD score recipients
}

\section{Comparação da evolução do transplante hepático em receptores com MELD alto e baixo}

\author{
Andre Ibrahim David ${ }^{1}$, Maria Paula Villela Coelho ${ }^{2}$, Angela Tavares Paes ${ }^{2}$, Ana Kober Leite ${ }^{1}$, \\ Bianca Della Guardia², Márcio Dias de Almeida ${ }^{2}$, Sergio Paiva Meira ${ }^{2}$, Marcelo Bruno de Rezende², \\ Rogerio Carballo Afonso², Ben-Hur Ferraz-Neto ${ }^{2}$
}

\begin{abstract}
Objective: To compare low and high MELD scores and investigate whether existing renal dysfunction has an effect on transplant outcome. Methods: Data was prospectively collected among 237 liver transplants (216 patients) between March 2003 and March 2009. Patients with cirrhotic disease submitted to transplantation were divided into three groups: MELD $\geq 30$, MELD $<30$, and hepatocellular carcinoma. Renal failure was defined as a $\pm 25 \%$ decline in estimated glomerular filtration rate as observed 1 week after the transplant. Median MELD scores were 35, 21, and 13 for groups MELD $\geq 30$, MELD $<30$, and hepatocellular carcinoma, respectively. Results: Recipients with MELD $\geq 30$ had more days in Intensive Care Unit, longer hospital stay, and received more blood product transfusions. Moreover, their renal function improved after liver transplant. All other groups presented with impairment of renal function. Mortality was similar in all groups, but renal function was the most important variable associated with morbidity and length of hospital stay. Conclusion: High MELD score recipients had an improvement in the glomerular filtration rate after 1 week of liver transplantation.
\end{abstract}

Keywords: Liver transplantation; End stage liver disease; Severity of illness index; Renal insufficiency; Glomerular filtration rate; Treatment outcome

\section{RESUMO}

Objetivo: Comparar MELDs altos e baixos, sua relação com a disfunção renal e 0 efeito no resultado do transplante. Métodos: Realizou-se coleta prospectiva de dados em 237 transplantes de fígado (216 pacientes) entre março de 2003 e março de 2009. Pacientes com cirrose submetidos a transplante foram divididos em três grupos: MELD $\geq 30, M E L D<30$, e carcinoma hepatocelular. Insuficiência renal foi definida como uma diminuição de $\pm 25 \%$ na taxa de filtração glomerular estimada, observada 1 semana após o transplante. As medianas do MELD foram 35, 21, e 13 para os grupos MELD $\geq 30$, MELD $<30$, e de carcinoma hepatocelular, respectivamente. Resultados: Receptores com MELD $\geq 30$ tiveram mais dias na Unidade de Terapia Intensiva, maior período de internação, e receberam mais transfusões de sangue. Além disso, sua função renal melhorou após o transplante de fígado. Os demais grupos apresentaram diminuição da função renal. A mortalidade foi semelhante em todos os grupos, mas a função renal foi a variável mais importante associada com morbidade e tempo de internação hospitalar. Conclusão: Em receptores com escores MELD altos houve melhora da taxa de filtração glomerular 1 semana após o transplante de fígado.

Descritores: Transplante de fígado; Doença hepática terminal; Índice de gravidade de doença; Insuficiência renal; Taxa de filtração glomerular; Resultado de tratamento

\section{INTRODUCTION}

The most frequent causes of liver disease are alcoholrelated (Laennec's cirrhosis), cholestatic disorders (congenital or acquired), and viral hepatitis. These are also the most common etiologies for orthotopic liver transplantation (OLT). According to the United Network for Organ Sharing (UNOS) ${ }^{(1)}$, a total of 15,758 candidates wait for an OLT in the United States alone. In Brazil, 6,505 patients wait for a liver transplant, according to the Associação Brasileira de Transplante de Órgãos (ABTO) ${ }^{(2)}$.

Until February 2002 (in the United States) and June 2006 (in Brazil), patients were considered for OLT

Study carried out at Hospital Israelita Albert Einstein - HIAE, São Paulo (SP), Brazil.

1 Hospital das Clínicas, Faculdade de Medicina, Universidade de São Paulo - USP, São Paulo (SP), Brazil.

${ }^{2}$ Hospital Israelita Albert Einstein - HIAE, São Paulo (SP), Brazil.

Corresponding author: Ben-Hur Ferraz-Neto - Avenida Albert Einstein, 627, consultório 208, bloco A1, $2^{\circ}$ andar - Morumbi - Zip code: $05652-900$ - São Paulo (SP), Brazil - Phone.: (11) 3747-3388 E-mail: ben-hur@einstein.br

Received on: Jul 19, 2011 - Accepted on: Dec 20, 2011

Conflicts of interest: None 
according to the Child-Turcotte-Pugh (CTP) score ${ }^{(3)}$, and therefore had to wait for a liver transplant depending exclusively on organ donor availability(4) and not on their own organ function indicators. After those dates, the Model for End-stage Liver Disease (MELD) began to be used and changed the listing criteria.

MELD was first described in 2000, with the aim to predict 3-month survival rates among patients undergoing transjugular intrahepatic portosystemic shunts (TIPS) ${ }^{(5,6)}$ Application of the MELD criteria to liver transplantation changed the allocation procedure from a waiting time-based to a risk-based system that considers the following variables: serum creatinine, bilirubin level, International Normalized Ratio (INR), and whether or not dialysis is required.

Since then, MELD scores have been used to identify potential recipients with higher death risk. Priority is given to high MELD score individuals as an attempt to decrease the mortality of patients on the waiting list for OLT.

As for patients with hepatocellular carcinoma (HCC), an adjusted MELD score is established according to tumor staging, in which a MELD score of 24 corresponds to T1, and of 29 to T2. For these patients, the adjusted MELD is necessary because of the risk of these patients being eliminated from the list due to tumor progression or metastasis ${ }^{(7)}$ Thus, these patients usually present with MELD scores < 30 .

While some authors showed that a high pretransplant MELD score may work as a predictor of postoperative complications ${ }^{(8,9)}$ others found no correlation between the MELD score and patient outcome after transplantation ${ }^{(10-13)}$. Therefore, despite the benefits of the MELD score system, investigators who adopt it as the main criterion for OLT must be aware of its limitations, which still impose the need for refinement.

Some researchers ${ }^{(9,14)}$ consider 25 as a high MELD score, while our group ${ }^{(15)}$ and others ${ }^{(13)}$ put the boundary at 30 or higher. As shown in other studies, successful OLT can be performed in patients presenting both high $\left(\right.$ MELD > 30) and low scores $(\text { MELD < 30) })^{(15)}$.

Improvements in outcomes following OLT increased long-term patient survival, which allowed identifying some long-term post-transplant complications. Chronic kidney disease (CKD) is one of these complications associated with decreased long-term patient survival, and a common one following liver transplant ${ }^{(16-20)}$. CKD is classified according to its severity and the treatment required, and disease progression can lead to a severe renal insufficiency that requires renal transplantation ${ }^{(21)}$.

Immunosuppressive drugs are nephrotoxic and therefore require careful pretransplant evaluation of renal function and close follow-up after OLT. Recent reports have described successful 1-year graft and patient survival rates (around 90\%) with administration of low doses of immunosuppressors ${ }^{(22,23)}$.

In high-MELD-score patients (range $\geq 30$ ), impaired renal function due to a hepatorenal syndrome or to nephropathy secondary to other diseases is usually present as well. Although it has been suggested that OLT in these patients may compromise the success of the procedure and lead to higher costs due to extra requirements for blood transfusions, hemodialysis, and longer stays in the Intensive Care Unit (ICU) or in the hospital ${ }^{(19)}$, researchers have reached no consensus.

Official data from the State of São Paulo, Brazil, on patients awaiting OLT reveal that their average MELD score is 29 . Such score may already be considered high for OLT, and is a consequence of the long waiting period on the OLT list because of insufficient deceased donors $^{(15)}$ and lack of transplant centers in some areas. In the United States, data from the UNOS suggest that longer waiting periods for OLT may start to occur there as well.

As the waiting list for an OLT is only getting longer, doctors and specialized centers should be better prepared to receive and treat patients presenting higher MELD scores. Thus, understanding the potential complications associated with using the MELD criteria and transplanting patients with higher MELD scores is now crucial.

\section{OBJECTIVE}

To compare low and high MELD score outcomes and investigate whether existing renal dysfunction has an effect on transplantation outcome.

\section{METHODS}

The study was approved by the local institutional review committee of Hospital Israelita Albert Einstein (HIAE), São Paulo, Brazil. Data were collected prospectively for 237 liver transplants performed in 216 patients ( 21 were retransplanted), between March 2003 and March 2009.

The MELD score was calculated considering serum creatinine, total serum bilirubin, and the INR according to the formula ${ }^{(24)}$ currently in use by UNOS and adopted by the State of São Paulo Health Department.

Patients with cirrhotic disease and submitted to OLT were divided into three groups: MELD $\geq 30$ (without HCC), MELD < 30 (without HCC), and HCC recipients. Patients who were considered as having 
priority, either because of severe acute hepatic failure or of need for retransplantation were excluded from this study.

Groups were compared regarding demographics, hepatic and renal function (measured by glomerular filtration rate - GFR), intraoperative blood product transfusions, length of stay in either the hospital or in the ICU, retransplantation, and early survival (30 days).

The immunosuppression protocol adopted was the same for all recipients and included a three-drug regimen with CNI, MMF or mycophenolate sodium, and steroids for the first 12 weeks.

Severe CKD was defined in accordance with the National Kidney Foundation Disease Outcomes Quality Initiative $^{(25)}$ as a GFR below $30 \mathrm{~mL} / \mathrm{min} / 1.73 \mathrm{~m}^{2}$. Renal failure was defined as the need for renal replacement therapy (RRT) in the form of chronic dialysis or kidney transplantation. Primary renal disease (PRD) was defined as a $\pm 25 \%$ decline in estimated post-transplant GFR. Calculation of GFR was performed with the modified diet in renal disease (MDRD) formula in its abbreviated form ${ }^{(21)}$ :

GFR $=186 \mathrm{x}$ serum creatinine $(\mathrm{mg} / \mathrm{dL})-1.154 \mathrm{x}$ age (years) $-0.203 \times 0.7422$ (if female)

\section{Statistical analysis}

Quantitative data were summarized by means and standard deviations (SD) when normally distributed, and by medians and range otherwise. Comparisons between the three groups were analyzed by one-way ANOVA and Kruskall-Wallis tests for normal and non-normal data, respectively. Categorical variables were compared by $\chi^{2}$ and Fisher's exact tests. The paired $t$ test was used to compare renal function parameters pre- and postliver transplant. For urea and creatinine levels, data were log-transformed to achieve a normal distribution. The significance level was 0.05 . Calculations were performed by Statistical Package for the Social Science software (SPSS, Chicago, Ill), version 17.0.

\section{RESULTS}

A total of 151 recipients of liver transplant were included in this study, which excluded individuals with severe acute hepatic failure or the need for retransplantation. They were divided into three groups: MELD $\geq 30$ $(\mathrm{n}=41), \operatorname{MELD}<30(\mathrm{n}=78)$, and HCC $(\mathrm{n}=32)$. All recipients had a deceased donor. Requirement for liver retransplantation did not differ among groups $(\mathrm{p}=0.439)$. Etiologies of cirrhosis are described on table 1.

There was statistical difference regarding the main causes of cirrhosis: in the HCC Group the highest
Table 1. Etiology of liver cirrhosis in each of the three groups

\begin{tabular}{lccc}
\hline $\begin{array}{l}\text { Etiology of liver } \\
\text { cirrhosis }\end{array}$ & $\begin{array}{c}\text { MELD } \geq \mathbf{3 0} \\
(\mathbf{n}=\mathbf{4 1 )} \\
\mathbf{n}(\%)\end{array}$ & $\begin{array}{c}\text { MELD }<\mathbf{3 0} \\
(\mathbf{n}=\mathbf{7 8}) \\
\mathbf{n}(\%)\end{array}$ & $\begin{array}{c}\text { HCC } \\
(\mathbf{n}=\mathbf{3 2}) \\
\mathbf{n}(\%)\end{array}$ \\
\hline HCV & $16(39.0)^{5}$ & $39(50)^{\S}$ & $24(75)$ \\
Laennec's cirrhosis & $12(29.3)$ & $11(14.1)^{*}$ & $3(9.4)^{*}$ \\
Cryptogenic & $6(14.6)$ & $9(11.5)$ & $1(3.1)$ \\
HBV & 0 & $11(14.1)$ & $4(12.5)$ \\
Chronic rejection & $2(4.9)$ & 0 & 0 \\
AlH & $1(2.4)$ & $2(2.6)$ & 0 \\
PBC & 0 & $3(3.8)$ & 0 \\
PSC & $1(2.4)$ & $2(2.6)$ & 0 \\
Caroli Disease & 0 & $1(1.3)$ & 0 \\
Others & $3(7.4)$ & 0 & 0
\end{tabular}

${ }^{5} p<0.05$ when compared to HCC; ${ }^{*} p<0.05$ when compared to MELD $\geq 30$.

$\mathrm{HCC}$ : hepatocellular carcinoma; $\mathrm{HCV}$ : hepatitis $\mathrm{C}$ virus; $\mathrm{HBV}$ : hepatitis B virus; AlH: autoimmune hepatitis; PBC: primary biliary cirrhosis; PSC: primary sclerosing cholangitis.

incidence was hepatitis $C$ virus, and in the MELD $\geq 30$ Group it was Laennec's cirrhosis.

Demographics and variables regarding postoperative follow-up are reported on table 2.

Table 2. Demographic and clinical variables for each of the three groups

\begin{tabular}{|c|c|c|c|}
\hline Demographics and variables & $\begin{array}{c}\text { MELD } \geq 30 \\
(\mathrm{n}=41)\end{array}$ & $\begin{array}{c}\text { MELD < } 30 \\
(n=78)\end{array}$ & $\begin{array}{c}\text { HCC } \\
(n=32) \\
\end{array}$ \\
\hline Age $^{*}$ & $52.3 \pm 13.5$ & $54.8 \pm 10.0$ & $56 \pm 6.9$ \\
\hline Male - n (\%) & $29(71 \%)$ & $57(73.1 \%)$ & $25(78.1 \%)$ \\
\hline $\mathrm{BMI}^{*}$ & $26.9 \pm 5.5$ & $26.4+4.1$ & $27.4 \pm 4.2$ \\
\hline Retransplantation - n (\%) & $1(2.4 \%)$ & $2(2.6 \%)$ & $2(6.3 \%)$ \\
\hline Days of ICU** & $5(1-103)$ & $2(0-104)^{\#}$ & $1(0-55)^{\#}$ \\
\hline Days of hospital stay** & $15(3-145)^{5}$ & $11(2-40)^{\S \#}$ & $9.0(5-32)$ \\
\hline
\end{tabular}

The MELD $\geq 30$ Group had a more prolonged hospital stay, mainly in the ICU, and the HCC Group had a shorter hospital stay. Renal function pretransplant was worse in patients in the MELD $\geq 30$ Group, improving after the transplant. For the MELD $<30$ Group, renal function had a statistically significant impairment after the transplant. Although the HCC Group presented with impairment as well, only urea levels were found to be statistically significant (Table 3 ).

GFR levels decreased with a statistical significance only for the MELD < 30 Group (Table 3). Of these patients, $20(48.8 \%)$ did not need hemodialysis in the early post-transplant period, $6(14.6 \%)$ required it only in the first days (less than 1 week after transplant), and $15(36.6 \%)$ for longer than 1 week. 
Patients in the MELD $\geq 30$ Group received more blood product transfusions than those in the other two groups (Table 4).

Recipient 3-month survival was similar in the three groups, with no statistical difference (Table 5).

Table 3. Renal function before and after liver transplant (within group comparisons)

\begin{tabular}{|c|c|c|c|}
\hline $\begin{array}{l}\text { Demographics and } \\
\text { variables }\end{array}$ & $\begin{array}{l}\text { MELD } \geq 30 \\
(n=41)\end{array}$ & $\begin{array}{c}\text { MELD }<30 \\
(n=78)\end{array}$ & $\begin{array}{c}\text { HCC } \\
(n=32)\end{array}$ \\
\hline \multicolumn{4}{|l|}{$\begin{array}{l}\text { Urea - median } \\
\text { (range) }\end{array}$} \\
\hline Pre tx & $73(16-240)$ & $29(8-144)$ & $29(14-89)$ \\
\hline Post P07 & $74.5(16.1-181)$ & $41(18-144)^{*}$ & $37(20-89)^{*}$ \\
\hline \multicolumn{4}{|l|}{$\begin{array}{l}\text { Creatinine - median } \\
\text { (range) }\end{array}$} \\
\hline Pre tx & $1.9(0.4-6.5)$ & $0.9(0.5-7.3)$ & $0.8(0.5-12.2)$ \\
\hline Post P07 & $1.3(0.4-3.8)^{*}$ & $1.3(0.6-5.4)^{*}$ & $1.1(0.4-5.4)$ \\
\hline \multicolumn{4}{|l|}{$\mathrm{GFR}-$ mean $\pm \mathrm{SD}$} \\
\hline Pre tx & $59.2 \pm 46.6$ & $88.1 \pm 39.0$ & $95.7 \pm 38.6$ \\
\hline Post P07 & $67.6 \pm 48.1$ & $67.0 \pm 44.1^{*}$ & $83.6 \pm 58.4$ \\
\hline
\end{tabular}

Table 4. Blood product transfusions in each of the groups

\begin{tabular}{lccc}
\hline Blood product transfusions & $\begin{array}{c}\text { MELD } \geq \mathbf{3 0} \\
(\mathbf{n}=\mathbf{4 1 )}\end{array}$ & $\begin{array}{c}\text { MELD }<\mathbf{3 0} \\
(\mathbf{n}=\mathbf{7 8})\end{array}$ & $\begin{array}{c}\text { HCC } \\
(\mathbf{n}=\mathbf{3 2})\end{array}$ \\
\hline OR - RBC units & $3(0-17)$ & $0(0-10)^{\#}$ & $0(0-5)^{\#}$ \\
OR - FFP units & $5(0-26)$ & $0(0-14)^{\#}$ & $0(0-10)^{\#}$ \\
OR - Platelet units & $0(0-10)$ & $0(0-1)^{\#}$ & $0(0-2)^{\#}$ \\
\hline
\end{tabular}

Values expressed as median (range).

* $\mathrm{p}<0.001$ when compared to MELD $\geq 30$

HCC: hepatocellular carcinoma; OR: operating room; RBC: red blood cell; FFP: fresh frozen plasma.

Table 5. Recipient survival in each of the three groups

\begin{tabular}{lccc}
\hline & $\begin{array}{c}\text { MELD } \geq \mathbf{3 0} \\
(\mathbf{n}=\mathbf{4 1})\end{array}$ & $\begin{array}{c}\text { MELD }<\mathbf{3 0} \\
(\mathbf{n}=\mathbf{7 8})\end{array}$ & $\begin{array}{c}\text { HCC } \\
(\mathbf{n}=\mathbf{3 2})\end{array}$ \\
\hline 3-month survival $n(\%)$ & $35(85.4)$ & $73(93.6)$ & $27(84.4)$ \\
\hline
\end{tabular}

HCC: hepatocellular carcinoma.

Recipient 3-month survival was $85.4 \%$ (35 patients) for the MELD $\geq 30$ Group, $93.6 \%$ (73 patients) for the MELD < 30 Group, and $84.4 \%$ (27 patients) for the HCC Group, with no statistically significant difference among them $(\mathrm{p}=0.119)$.

\section{DISCUSSION}

The most frequent causes of liver cirrhosis were similar in the three groups. As expected, patients with higher
MELD scores experienced longer ICU and hospital stays. The requirement for intraoperative blood product transfusions occurred more often among patients in the MELD $\geq 30$ Group than in those in the MELD $<30$ Group (Table 4), with the exception of one patient with a high MELD score who did not require any transfusion. There was no difference in retransplantation incidence and in the three-month survival rate among the groups. Early survival rates in this study were comparable to survival rates found in literature ${ }^{(3,15)}$ and registries ${ }^{(1,26)}$.

Ravaioli et al. ${ }^{(13,27)}$ found no correlation between survival outcomes after liver transplantation and recipient MELD scores. In contrast, some authors used the MELD score established immediately before the procedure, or the score calculated during the first week after surgery, as a predictor of patient survival ${ }^{(28)}$. We observed a similar survival rate among the groups. In our study, we did not note worse early survival rate outcomes after liver transplantation in higher MELD score patients. This finding supports some prior results described by our group when working with a smaller group of patients ${ }^{(15)}$.

The MELD system allocation leads to the identification of the sickest patients, allowing them to be given priority on the OLT list. Perhaps a better approach for liver allocation, as some authors suggested ${ }^{(27)}$, would be based on giving priority to those patients at a higher risk of dropping out from the list, but with a good prospect for survival after OLT. Another consideration is the quality of the graft used for the sickest patients. Some authors suggested that best results were achieved when using optimal donors in higher risk recipients ${ }^{(14,29)}$.

PRD and CKD are common complications after liver transplantation and are associated with poor clinical outcomes, including dependence on hemodialysis, kidney transplant, cardiovascular disease, and death. Liver transplant recipients with $\mathrm{HCV}$ are known to have an increased risk for $\mathrm{CKD}^{(22)}$. Recipients with nephrotoxicity after liver transplantation who received MMF with a subsequent CNI dose reduction show improvement in renal function ${ }^{(22,29)}$. We used a threedrug regimen that included CNI, steroids, and MMF or mycophenolate sodium, and obtained a lower rate of PRD. Liver transplant recipients with MELD $\geq 30$ scores showed improved GFR after the transplant. Although GFR decreased in the two other groups, no significant renal dysfunction was observed (Table 3).

We questioned whether existing renal dysfunction after one week of the procedure has a significant effect on morbidity and mortality of OLT patients and what this effect might be when low and high MELD scores 
are considered. Even though we have found similar survival rates among groups, the lengths of hospital and ICU stays were longer in the high MELD Group, and the incidence of PRD was greater.

\section{CONCLUSION}

Greater renal function compromise increased morbidity while no changes in mortality were observed in the three groups, although renal patients required more resources. High MELD recipients had an improvement in GFR after one week of OLT.

\section{Acknowledgements}

We would like to thank Marcia Triunfol, at Publicase, for her kind assistance in manuscript review and comments.

\section{REFERENCES}

1. Liver recipient all ABO. UNOS/OPTN. http://www.optn.org/latestData/rptData. asp $>2009$

2. Associação Brasileira de Transplante de Órgãos. Registro Brasileiro de Transplante Jan/Dez 2009 [Internet]. São Paulo: Lado a Lado Comunicação e Marketing [citado 2012 Mar 4]. Disponível em: http://sctransplantes.saude. sc.gov.br/images/stories/rbt 2009.pdf

3. Kamath PS, Kim WR. Advanced Liver Disease Study Group. The model for end-stage liver disease (MELD). Hepatology. 2007:45(3):797-805.

4. Sachdev M, Hernandez JL, Sharma P, Douglas DD, Byrne T, Harrison ME, et al. Liver transplantation in the MELD era: a single-center experience. Dig Dis Sci. 2006;51 (6):1070-8.

5. Malinchoc M, Kamath PS, Gordon FD, Peine CJ, Rank J, ter Borg PC. A model to predict poor survival in patients undergoing transjugular intrahepatic portosystemic shunts. Hepatology.2000; 31(4):864-71.

6. Washburn WK, Pollock BH, Nichols L, Speeg KV, Halff G. Impact of recipient MELD score on resource utilization. Am J Transplant. 2006;6(10):2449-54.

7. Yao FY, Bass NM, Nikolai B, Merriman R, Davern TJ, Kerlan R, et al. A followup analysis of the pattern and predictors of dropout from the waiting list for liver transplantation in patients with hepatocellular carcinoma: implications for the current organ allocation policy. Liver Transpl. 2003;9(7):684-92.

8. Yu JW, Wang GQ, Li SC. Prediction of the prognosis in patients with acute-onchronic hepatitis using the MELD scoring system. J Gastroenterol Hepatolol. 2006;21(10):1519-24.

9. Onaca NN, Levy MF, Netto GJ, Thomas MJ, Sanchez EQ, Chinnakotla S, et al. Pretransplant MELD score as a predictor of outcome after liver transplantation for chronic hepatitis C. Am J Transplant. 2003;3(5):626-30.

10. Silberhumer GR, Hetz H, Rasoul-Rockenschaub S, Peck-Radosavljevic M, Soliman $T$, Steininger $\mathrm{R}$, et al. Is MELD score sufficient to predict not only death on waiting list, but also post-transplant survival? Transplant Int. 2006; 19(4):275-81

11. Adler M, De Gendt E, Vereerstraeten P, Degré D, Bourgeois N, Boon N, et al. Value of the MELD score for the assessment of pre- and post-liver transplantation survival. Transplant Proc. 2005;37(6):2863-4.

12. Cholongitas E, Marelli L, Shusang V, Senzolo M, Rolles K, Patch D, et al. A systematic review of the performance of the model for end-stage liver disease (MELD) in the setting of liver transplantation. Liver Transpl. 2006;12(7):1049-61.

13. Ravaioli M, Grazi GL, Ballardini G, Cavrini G, Ercolani G, Cescon M, et al. Liver transplantation with the Meld system: a prospective study from a single European center. Am J Transplant. 2006;6(7):1572-7.

14. Sun J, Guo ZH, Lai TS, Tang YQ, Su L, Huo F, et al. Clinical value of the model for end-stage liver disease score in predicting the prognosis of liver transplantation in patients with end-stage liver disease. Nan Fang Yi Ke Da Xue Xue Bao. 2008;28(9):1731-2, 1742

15. Ferraz-Neto BH, Zurstrassen MP, Hidalgo R, Meira-Filho SP, Rezende MB, Paes AT, et al. Analysis of liver transplantation outcome in patients with MELD Score $>$ or $=30$. Transplant Proc. 2008;40(3):797-9.

16. Kim DY, Lim C, Parasuraman R, Raoufi M, Yoshida A, Arenas J, et al. Renal disease burden following liver transplantation. Transplant Proc. 2006;38(10): 3663-5.

17. O'Riordan A, Wong V, McCormick PA, Hegarty JE, Watson AJ. Chronic kidney disease post-liver transplantation. Nephrol Dial Transplant. 2006;21 (9):2630-6.

18. Guitard J, Ribes D, Kamar N, Muscari F, Cointault O, Lavayssière L, et, AL. Predictive factors for chronic renal failure one year after orthotopic liver transplantation. Ren Fail. 2006;28(5):419-25.

19. Cohen AJ, Stegall MD, Rosen CB, Wiesner RH, Leung N, Kremers WK, et al. Chronic renal dysfunction late after liver transplantation. Liver Transpl. 2002;8(10):916-21.

20. Morard I, Mentha G, Spahr L, Majno P, Hadengue A, Huber O, et al. Long-term renal function after liver transplantation is related to calcineurin inhibitors blood levels. Clin Transplant. 2006;20(1):96-101.

21. National Kidney Foundation. K/DOOI clinical practice guidelines for chronic kidney disease: evaluation, classification, and stratification. Am J Kidney Dis. 2002;39(2 Suppl 1):S1-266.

22. Lake J, Patel D, David K, Richwine J, Morris J. The association between MMF and risk of progressive renal dysfunction and death in adult liver transplant recipients with HCV. Clin Transplant. 2009;23(1):108-15.

23. Dharancy S, lannelli A, Hulin A, Declerck N, Schneck AS, Mathurin $P$, et al Mycophenolate mofetil monotherapy for severe side effects of calcineurin inhibitors following liver transplantation. Am J Transplant. 2009;9(3):610-3.

24. Kamath PS, Wiesner RH, Malinchoc M, Kremers W, Therneau TM, Kosberg $\mathrm{CL}$, et al. A model to predict survival in patients with end-stage liver disease. Hepatology. 2001;33(2):464-70.

25. National Kidney Foundation. The National Kidney Foundation Kidney Disease Outcomes Quality Initiative (NKF KDOOI IM) [Internet]. 2012 [cited 2012 Jan 31]. Available from: http://www.kidney.org/Professionals/kdogi

26. Liver recipients data.Data E. Available from: http://www.eltr.org/publi/results. php3?id rubrique $=48$.

27. Ravaioli $\bar{M}$, Grazi GL, Ercolani G, Cescon M, Pinna AD, Ballardini G. The future challenge in the MELD era: how to match extended-use donors and sick recipients. Transplantation. 2006; 82(7):987-8.

28. Cholongitas E, Marelli L, Shusang V, Senzolo M, Rolles K, Patch D, et al. A systematic review of the performance of the model for end-stage liver disease (MELD) in the setting of liver transplantation. Liver Transpl. 2006;12(7):1049-61.

29. Desai NM, Mange KC, Crawford MD, Abt PL, Frank AM, Markmann JW et al. Predicting outcome after liver transplantation: utility of the model for end-stage liver disease and a newly derived discrimination function. Transplantation. 2004;77(1):99-106. 